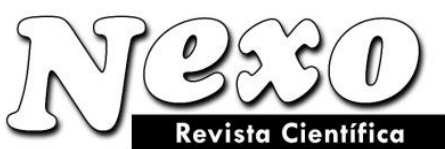

Vol. 33, No. 02, pp. 368-377/Diciembre 2020

\title{
Change in sowing date combined with water stress affects canola seed oil and fatty acid composition
}

\section{El cambio en la fecha de siembra combinado con el estrés hídrico afecta la composición del aceite de semilla de canola y los ácidos grasos}

\author{
Zahra Biyouk $^{1}$, Saeed Sayfzadeh ${ }^{1 *}$, Hamidreza Zakerin ${ }^{1}$, Amir Hossein Shirani Rad ${ }^{2}$, \\ Esmaeil Hadidi Masouleh ${ }^{1}$ \\ 1 Department of Agronomy, Faculty of Agriculture, Takestan Branch, Islamic Azad University, \\ Takestan, Iran. \\ 2 Seed and Plant Improvement Institute (SPII), Agricultural Research, Education and Extension \\ Organization (AREEO), Karaj, Iran.
}

* Corresponding author: Saeed Sayfzadeh, ssayfzadeh2000@ gmail.com

\begin{abstract}
To study the effect of sowing date and water stress on qualitative traits of canola, an experiment was conducted for two years in Iran. The sowing date and irrigation were in two levels as the main factors, and five canola cultivars and hybrids were included as the subfactors. In normal sowing date and normal irrigation conditions, The Tassilo hybrid with a high seed yield and seed oil yield (6139 and $2905 \mathrm{~kg} \mathrm{ha}^{-1}$, respectively) can be effective in the cultivation of canola in temperate cold regions with dry and semi-arid climates. In the conditions of delayed cultivation and late season drought stress, the same hybrid with the highest seed yield and seed oil yield (2935 and $1273 \mathrm{~kg} \mathrm{ha}^{-1}$, respectively) and the least amount of erucic acid $(0.4 \%)$ and glucosinolate content $\left(22.9 \mu \mathrm{mol} \mathrm{\textrm {g } ^ { - 1 }}\right)$ is recommended for the delayed cultivation conditions together with late season drought stress.
\end{abstract}

Keywords: Canola; delayed cultivation; fatty acids composition; drought stress; oil content

\section{RESUMEN}

Para estudiar el efecto de la fecha de siembra y el estrés hídrico en los rasgos cualitativos de la canola, se llevó a cabo un experimento durante dos años en Irán. La fecha de siembra y el riego estuvieron en dos niveles como factores principales, y se incluyeron cinco cultivares e híbridos de canola como subfactores. En fecha normal de siembra y condiciones normales de riego, el híbrido de Tassilo con un alto rendimiento de semilla y aceite de semilla (6139 y $2905 \mathrm{~kg}$ ha-1, respectivamente) puede ser eficaz en el cultivo de canola en regiones templadas frías con secas y semiáridas. climas. En las condiciones de cultivo tardío y estrés por sequía tardía, el mismo híbrido con mayor rendimiento de semilla y rendimiento de aceite de semilla (2935 y $1273 \mathrm{~kg}$ ha-1, respectivamente) y la menor cantidad de ácido erúcico (0,4\%) y contenido de glucosinolato ( $22,9 \mu \mathrm{mol} \mathrm{g}$-1) se recomienda para las condiciones de cultivo tardías junto con el estrés por sequía al final de la temporada. 
Palabras llave: Canola; cultivo retrasado; composición de ácidos grasos; estrés por sequía; contenido de aceite

\section{INTRODUCTION}

Canola (Brassica napus L.) is one of the most important oily seeds in the world, whose importance is due to the high quality of its oil and meal that has the potential of a renewable source of biofuels (Qian et al., 2009). Due to its low content of saturated fatty acids, a low level of unsaturated fatty acids and lack of cholesterol, canola oil has high nutritional quality (Starner, Hamama, \& Bhardwaj, 2002). The combination of fatty acids in canola oil is similar to olive and peanut oil but with lesser palmitic acid and higher linoleic acid (Seyed Sharifi, 2017).

Drought stress in any stage of plant's life affects its growth, but the amount and severity of damage, the damage compensation capacity and its effect on the final product depend on the developmental stage when the plant is under stress (Farooq, Wahid, Kobayashi, Fujita, \& Basra, 2009). The effect of drought stress on canola yield is a function of genotype, severity and duration of stress, as well as climate conditions and developmental stages (Majidi, 2015). In an irrigation management plan, the information about the plant, soil, climate, irrigation system, water distribution method, and management objectives should be considered. This is very important especially to arid and semi-arid areas where water resources are very limited (Hanson, Schwankl, \& Fulton, 1999).

Canola is one of the agricultural crops heavily dependent on farm management and its yield can be improved by observing breeding and crop improvement principles. To this end, besides introducing high yielding cultivars, the maximum genetic capacity of the cultivars can also be used in different climatic conditions that part of this objective can be gained by employing management practices such as sowing at the right time to improve the quantitative and qualitative yield of canola. Sowing date is an important factor affecting seed yield, oil content and fatty acid composition (Koutroubas \& Papakosta, 2005). The qualitative characteristics of any type of oil depends on its fatty acids composition, especially oleic, linoleic and erucic fatty acids that are highly influenced by environmental conditions (Enjalbert et al., 2013) and cultivar type (Nasr, Khayami, Heydari, \& Jameei, 2006). Hence, it is very important to determine the appropriate planting date to match the emergence of plant phonological stages with environmental factors.

The two most important factors threatening the development of the cultivated area and the successful production of canola are late season drought stress and the impossibility of timely cultivation of canola in the fall. One of the fundamental strategies in this regard is the selection of advanced cultivars and hybrids of canola with simultaneously two characteristics of cold and frost resistance in the early stages of growth (four to six leaves) and drought tolerance (two less irrigations) in the late stages of growth. Therefore, the selection of superior cultivar(s) in terms of quantitative and qualitative traits can be effective in increasing the cultivation area of canola to more than 150 thousand hectares through preserving the quality of the produced oil and meal, and this is a developmental innovation of the present research.

\section{MATERIALS AND METHODS}

To evaluate the effect of sowing date and water stress on quantitative and qualitative traits of canola cultivars and hybrids, a factorial split plot experiment was conducted in a randomized complete block design with three replications at the Seed and Plant Improvement Institute in Karaj, Iran during 2015-16 and 2016-17 at the longitude $6^{\prime}$ and $51^{\circ}$ east and latitude 59' and $35^{\circ}$ northeast and altitude of $1160 \mathrm{~m}$ above sea level. Based on the average 30-year data of Karaj meteorological center, the average annual rainfall in the region is $243 \mathrm{~mm}$, and precipitation mainly occurs in late fall and early spring.

In this study, sowing date was determined in two levels: timely cultivation (September 27: sowing with strong rosette with frost and cold winter conditions), and delayed cultivation (October 27: plant entry in the early stages of growth of four to six leaves to frost and cold winter conditions). Irrigation also included 
two levels of normal irrigation (control) and irrigation interruption from the podding stage as the main factor and canola cultivars and hybrids included Kodiak, Traviata, Compass, Diffusion, Mehr2, Elvise and Tassilo were included as the sub-factors. Each experiment plot consisted of six lines of six meters long, spaced by lines of $30 \mathrm{~cm}$ and the two sidelines were considered as margins. Plant spacing on the sowing lines was $5 \mathrm{~cm}$. The consumed fertilizers based on soil test were 1) $150 \mathrm{~kg} \mathrm{ha}^{-1}$ of ammonium phosphate and $150 \mathrm{~kg} \mathrm{ha}^{-1}$ of potassium sulfate as the basis simultaneously with preparing seed bed, 2) $350 \mathrm{~kg} \mathrm{ha}^{-1}$ of urea (100 kg in three-leaf stage, $150 \mathrm{~kg}$ in stemming stage and $100 \mathrm{~kg}$ in budding stage) in the bidding form. Irrigation intervals were calculated based on $80 \mathrm{~mm}$ evaporation from class A evaporation pan and the amount of water consumed at each irrigation time was $80 \%$ of the evaporated water. The amount of entering water to the farm was measured by a counter. The number of irrigations in timely cultivation in the control treatments and irrigation interruption from podding stage were 8 and 6 times, respectively; and in delayed cultivation, they were 7 and 5 times, respectively. Moreover, the amount of water consumed in the abovementioned treatments was 5120 and $3840 \mathrm{~m}^{3} \mathrm{ha}^{-1}$ in timely cultivation and 4480 and $3200 \mathrm{~m}^{3} \mathrm{ha}^{-}$

${ }^{1}$ for delayed cultivation, respectively.

To determine the seed yield, the plants in the 4.8 square meter area of each single plot were technically cut and weighed accurately. In order to determine the percentage of seed oil, a 5-gram sample was randomly selected from each plot and its percentage was determined by NMR (Nuclear Magnetic Resonance) (ISO, 1992). After determination of the seed oil percentage, seed oil yield in $\mathrm{kg} \mathrm{ha}^{-1}$ was calculated from the product of multiplying it by the seed yield. To measure and determine the fatty acids in the seed oil, gas chromatography method was employed (Damirchi, Savage, \& Dutta, 2005). The amount of seed's glucosinolate was measured by spectrophotometer (Makkar, Siddhuraju, \& Becker, 2007).

Finally, after assuring the test assumptions before and after the combined ANOVA, Bartlett's test was conducted to homogenize the variances. Then, the combined ANOVA was performed using SAS software version 9.2. The comparison of the means was performed using the least significant difference test at $\mathrm{p}<$ 0.05 . Excel software was used to draw charts.

\section{RESULTS AND DISCUSSION}

The simple effect of year on seed yield, seed oil yield, palmitic acid, oleic acid and glucosinolate was significant at the level of $1 \%$. The simple effect of sowing date and simple effect of irrigation on all traits were significant at the level of $1 \%$. The cultivars were significantly different in terms of traits of seed yield, seed oil content, seed oil yield, palmitic acid, oleic acid, linoleic acid, erucic acid and glucosinolate at the level of $1 \%$ and in terms of traits of linolenic acid at the level of $5 \%$. The interaction effect of sowing date $\times$ irrigation on the seed yield, seed oil content and seed oil yield was significant at the level of $5 \%$ and in terms of linoleic acid, it was significant at the level of $1 \%$. In addition, the interaction effect between sowing date $\times$ cultivar on palmitic acid trait was significant at the level of $1 \%$. Furthermore, the interaction effect of sowing date $\times$ irrigation $\times$ cultivar on the traits of seed yield and seed oil yield was significant at the level of $1 \%$ and about the traits of linoleic acid, linolenic acid, erucic acid and glucosinolate of seed it was significant at the level of $5 \%$.

\section{Seed Yield}

The significant difference between the responses of cultivars to irrigation treatments in timely and delayed sowing dates showed that in timely sowing date (September 27) under normal irrigation and irrigation interruption from pudding stage, Tassilo hybrid showed the highest seed yield with mean of 6139 and $4918 \mathrm{~kg} \mathrm{ha}^{-1}$, respectively. In delayed sowing date (October 27) and in the late season drought stress conditions (irrigation interruption from podding stage), the same hybrid had the highest seed yield with the mean of $2935 \mathrm{~kg} \mathrm{ha}^{-1}$ (Table 1).

Comparison of the tested cultivars on the timely sowing date (September 27) showed that Compass hybrid had the lowest seed yield loss (15.9\%) in irrigation interruption from podding stage compared to the normal irrigation, while in the delayed sowing date (October 27), the promising line of Mehr2 (Mahtab 
cultivar) showed the lowest seed yield loss (19.3\%) in irrigation interruption from podding stage compared to the normal irrigation (Table 1). In canola plant, the flowering and podding stages are considered to be the most sensitive stages to drought stress (Sinki et al., 2007). Also Faraji et al. (2009) reported that delayed sowing date of canola reduced the growth period and eventually decreased the seed yield.

Table 1. Mean comparisons of interaction effects of planting date, irrigation, and cultivar on some qualitative characteristics

\begin{tabular}{|c|c|c|c|c|c|}
\hline Planting date & Irrigation & Cultivar & $\begin{array}{l}\text { Seed yield } \\
\left(\mathrm{kg} \mathrm{ha}^{-1}\right)\end{array}$ & $\begin{array}{l}\text { Oil yield } \\
\left(\mathrm{kg} \mathrm{ha}^{-1}\right)\end{array}$ & $\begin{array}{l}\text { Linoleic acid } \\
(\%)\end{array}$ \\
\hline \multirow{15}{*}{ Sep. 27} & \multirow{7}{*}{ Control } & Kodiak & $5560^{\mathrm{ab}}$ & $2589^{a b}$ & $18.6^{\mathrm{ab}}$ \\
\hline & & Traviata & $5281^{\mathrm{b}}$ & $2438^{b}$ & $18.3^{\mathrm{b}}$ \\
\hline & & Compass & $5205^{\mathrm{b}}$ & $2398^{b}$ & $18.2^{\mathrm{b}}$ \\
\hline & & Diffusion & $5642^{a b}$ & $2635^{a b}$ & $18.8^{\mathrm{ab}}$ \\
\hline & & Mehr2 & $5028^{\mathrm{b}}$ & $2306^{\mathrm{b}}$ & $18.0^{\mathrm{b}}$ \\
\hline & & Elvise & $5752^{\text {ab }}$ & $2694^{\mathrm{ab}}$ & $18.9^{\mathrm{ab}}$ \\
\hline & & Tassilo & $6139 \mathrm{a}$ & $2905^{\mathrm{a}}$ & $19.2^{\mathrm{a}}$ \\
\hline & Lsd (0.05) & & 853.08 & 398.17 & 0.90 \\
\hline & \multirow{7}{*}{ Restricted irrigation from pod formation } & Kodiak & $3973^{b c}$ & $1774^{\mathrm{bc}}$ & $16.7^{\mathrm{bc}}$ \\
\hline & & Traviata & $3770^{c}$ & $1679^{c}$ & $16.4^{\mathrm{c}}$ \\
\hline & & Compass & 4377 abc & $1979^{\mathrm{abc}}$ & $17.3^{\mathrm{abc}}$ \\
\hline & & Diffusion & $4474 \mathrm{abc}$ & $2025^{\mathrm{abc}}$ & $17.4^{\mathrm{abc}}$ \\
\hline & & Mehr2 & 4053 bc & $1816^{\mathrm{bc}}$ & $16.9^{a b c}$ \\
\hline & & Elvise & $4562^{a b}$ & $\mathrm{Ab} 2073^{\mathrm{ab}}$ & $17.5^{\mathrm{ab}}$ \\
\hline & & Tassilo & $4918^{\mathrm{a}}$ & $2248^{\mathrm{a}}$ & $17.9^{\mathrm{a}}$ \\
\hline \multirow{17}{*}{ Oct. 27} & Lsd (0.05) & & 786.64 & 348.04 & 1.02 \\
\hline & \multirow{7}{*}{ Control } & Kodiak & $3114^{\mathrm{a}}$ & $1354^{\mathrm{a}}$ & $15.2^{\mathrm{a}}$ \\
\hline & & Traviata & $3295^{a}$ & $1439^{\mathrm{a}}$ & $15.6^{\mathrm{a}}$ \\
\hline & & Compass & $3413^{\text {a }}$ & $1497^{\mathrm{a}}$ & $15.7^{\mathrm{a}}$ \\
\hline & & Diffusion & $3489^{\text {a }}$ & $1534^{\mathrm{a}}$ & $15.9^{\mathrm{a}}$ \\
\hline & & Mehr2 & $3135^{\mathrm{a}}$ & $1364^{\mathrm{a}}$ & $15.3^{\mathrm{a}}$ \\
\hline & & Elvise & $3537^{a}$ & $1559^{a}$ & $15.9^{\mathrm{a}}$ \\
\hline & & Tassilo & $3634^{\mathrm{a}}$ & $1602^{a}$ & $16.2^{\mathrm{a}}$ \\
\hline & Lsd (0.05) & & 906.42 & 398.31 & 1.14 \\
\hline & \multirow{7}{*}{ Restricted irrigation from pod formation } & Kodiak & $2371^{a b}$ & $1016^{\mathrm{ab}}$ & $14.4^{\mathrm{b}}$ \\
\hline & & Traviata & $2149^{b}$ & $918.2^{\mathrm{b}}$ & $14.2^{\mathrm{b}}$ \\
\hline & & Compass & $2318^{\mathrm{b}}$ & $1003^{\mathrm{b}}$ & $14.4^{b}$ \\
\hline & & Diffusion & $2652^{a b}$ & $1141^{\mathrm{ab}}$ & $14.6^{\mathrm{ab}}$ \\
\hline & & Mehr2 & $2527^{a b}$ & $1081^{\mathrm{ab}}$ & $14.5^{\mathrm{b}}$ \\
\hline & & Elvise & $2729^{a b}$ & $1179^{\mathrm{ab}}$ & $14.6^{a b}$ \\
\hline & & Tassilo & $2935^{\text {a }}$ & $1273^{\mathrm{a}}$ & $15.4^{\mathrm{a}}$ \\
\hline & Lsd (0.05) & & 600.84 & 265.64 & 0.89 \\
\hline
\end{tabular}

Any two means sharing a common letter do not differ significantly from each other at $5 \%$ probability

\section{Seed Oil Content}

The significant difference was observed between the seed oil contents of the studied cultivars, so that Tassilo hybrid with the mean of $45 \%$ had the highest seed oil content compared to other cultivars (Figure 1). Comparison of the mean of interaction effect of sowing date $\times$ irrigation showed that the average seed oil content on the timely sowing date (September 27) in normal irrigation treatments (control) and irrigation interruption from the podding stage was $46.5 \%$ and $45.1 \%$, respectively (Figure 2). 
Nevertheless, the mean of this trait in delayed sowing date (October 27) was $43.7 \%$ and $43 \%$, respectively in normal irrigation and late season drought stress (irrigation interruption from the podding stage) (Figure 2).

According to the results, the percentage of seed oil loss in timely sowing date and normal irrigation compared to the delayed sowing date and normal irrigation was 6\%. In addition, the percentage of seed oil loss in timely sowing date and late season drought stress compared to the delayed sowing date and late season drought stress was 4.6\%. Adamsen and Coffelt (2005) also reported the decreased seed oil content due to the delayed sowing date.

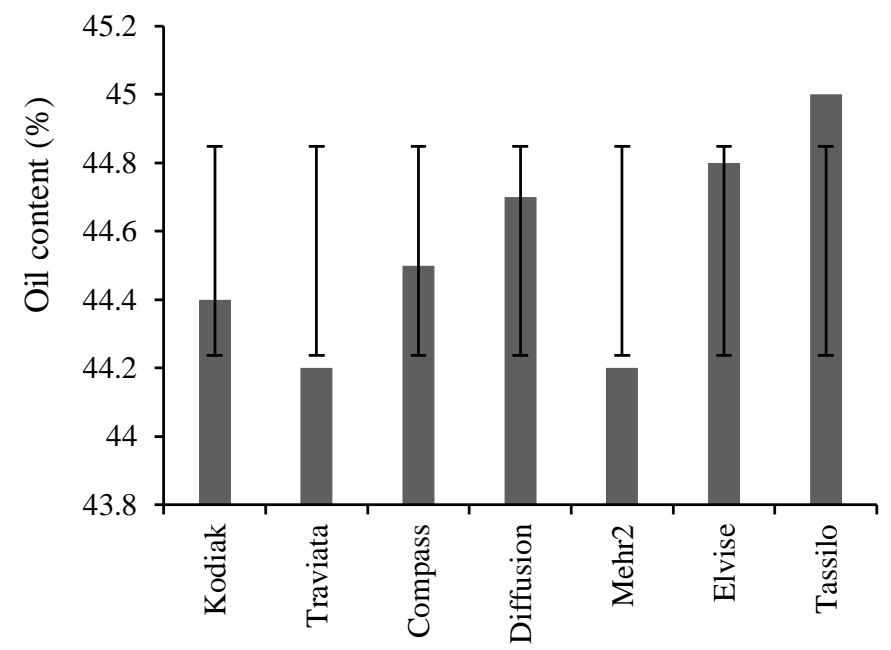

Cultivar

Figure 1. Mean comparison of simple effect of cultivar on oil content (The vertical bars indicated LSD).

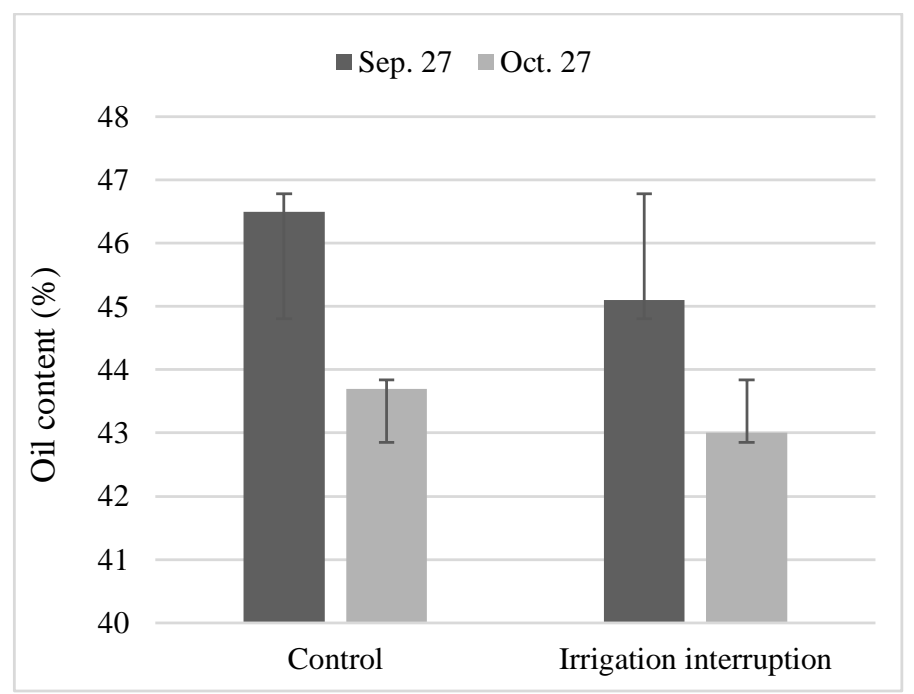

Figure 2. Mean comparison of interaction effect of sowing date $\times$ irrigation on oil content (The vertical bars indicated LSD).

\section{Seed Oil Yield}

The responses of cultivars to irrigation treatments was significantly different in timely and delayed sowing dates, so that in timely sowing date (September 27), under normal irrigation and irrigation interruption from podding stage, the Tassilo hybrid had the highest seed yield with the means of 2905 and $2248 \mathrm{~kg} \mathrm{ha}^{-}$ 
${ }^{1}$, respectively. On the delayed sowing date (October 27) under irrigation interruption from the podding stage, the same hybrid showed the highest seed oil yield with the mean of $1273 \mathrm{~kg} \mathrm{ha}^{-1}$ ) (Table 1). Given the dependence of seed oil yield on canola seed yield, this result was predictable.

The results of comparing the tested cultivars on the timely sowing date (September 27) showed that Compass hybrid had the lowest seed-oil yield loss (17.4\%) in the late season drought stress compared to the normal irrigation conditions. In addition, in the delayed sowing date (October 27) under irrigation interruption from podding stage, the Tassilo hybrid had the lowest seed yield loss (20.5\%) compared to the normal irrigation conditions (Table 1). On favorable sowing date, with the high seed yield and oil content, canola produces the highest seed oil yield, while delayed sowing date reduces seed yield, seed oil content and, finally, the seed oil yield due to reduced plant growth, contact with heat during the seedfilling stage, increased respiration and reduced photosynthetic materials (Daneshian, Ahmadzadeh, Shahriar, \& Khanizadeh, 2008).

\section{Palmitic Acid}

Comparison of the mean simple effect of sowing date revealed that delayed cultivation reduced the palmitic acid content by $13.2 \%$ compared to the timely sowing date (Figure 3 ).

Comparison of the mean interaction effect of irrigation $\times$ cultivar by cutting method indicated that in normal irrigation treatments (control) and irrigation interruption from the podding stage, Tassilo hybrid had the highest amount of this saturated fatty acid with the means of 5.3\% and 4.9\%, respectively (Figure 4). The amount of palmitic and stearic fatty acids depends on various parameters such as genotype and the severity of drought stress; and the amount of these fatty acids may be increased or reduced under drought stress conditions according to genotype (Kadkhodaie, Razmjoo, Zahedi, \& Pessarakli, 2014).

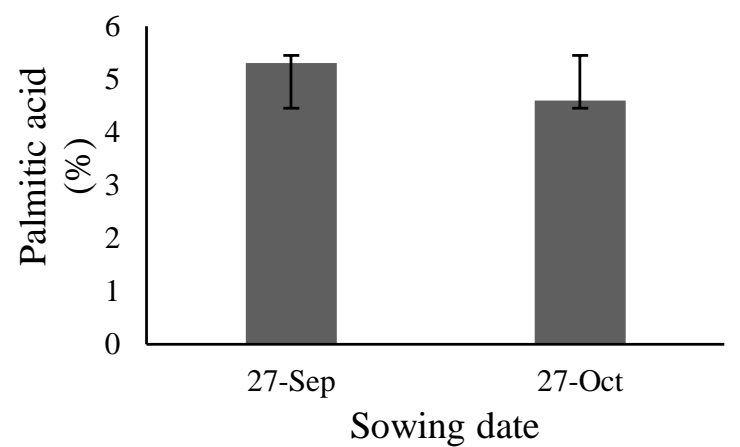

Figure 3. Mean comparison of simple effect of sowing date on palmitic acid (The vertical bars indicated LSD).

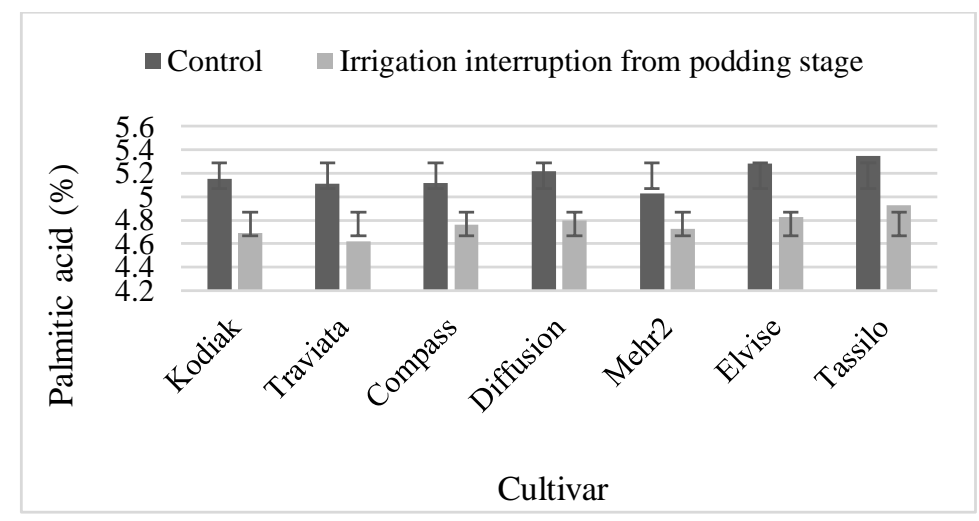

Figure 4. Mean comparison of interaction effect of irrigation $\times$ cultivar on palmitic acid (The vertical bars indicated LSD). 


\section{Oleic Acid}

The mean percentage of oleic acid was significantly different in timely (September 27) and delayed (October 27 ) sowing dates and delayed cultivation slightly reduced (1.9\%) oleic acid $(\omega 9)$ compared to the timely sowing date (Figure 5).

Comparison of the mean interaction effect of irrigation $\times$ cultivar revealed that under normal irrigation (control), Tassilo and Elvise hybrids with the mean of $66 \%$ and in irrigation interruption conditions from podding stage, Tassilo hybrid with the mean of $65 \%$ had the highest amount of this saturated fatty acid (Figure 6), while under normal irrigation (control), the promising line of Mehr2 (Mahtab cultivar) had the lowest percentage of oleic acid loss $(0.7 \%)$ compared to the late season drought stress condition. Flagella et al. (2002) also emphasized the effect of different environmental conditions on the oleic acid content in different regions (Flagella, Rotunno, Tarantino, Di Caterina, \& De Caro, 2002).

\section{Linoleic Acid}

The responses of cultivars to timely and delayed cultivation dates at different levels of irrigation were different. Comparison of means by cutting method revealed that in timely sowing date (September 27) in normal irrigation treatments and irrigation interruption from podding stage, Tassilo hybrid had the highest amount of linoleic acid ( $\omega 6)$ with the means of 19.2 and $17.9 \%$, respectively. In addition, in the delayed sowing date (October 27), in the irrigation interruption from podding stage, the same hybrid with the mean of $15.4 \%$ had the highest amount of this unsaturated fatty acid (Table 1). The quality of canola seed oil is mainly determined by the amount of oleic, linoleic and erucic fatty acids and highly influenced by environmental conditions (Enjalbert et al., 2013), cultivar type (Javidfar et al., 2007; Nasr et al., 2006) as well as the length of the phonological stages (Pritchard, Eagles, Norton, Salisbury, \& Nicolas, 2000).

\section{Linolenic Acid}

Different responses of cultivars to timely and delayed sowing dates in irrigation treatments showed that on the timely sowing date (September 27) and normal irrigation (control), the cultivars of Traviata, Compass and Mehr2 (Mahtab cultivar) promising lines had the highest amount of linolenic acid $(\omega 3)$ with the mean of $5 \%$. However, in other experimental treatments, the responses of the cultivars to this unsaturated fatty acid were not significantly different (Table 2). An increase of 1.7 to $2 \%$ was reported for the linolenic unsaturated fatty acid in canola seed oil due to drought stress in Mediterranean climate conditions (Aslam et al., 2009).

Table 2. Mean comparisons of interaction effects of planting date, irrigation, and cultivar on some qualitative characteristics

\begin{tabular}{|c|c|c|c|c|c|}
\hline Planting date & Irrigation & Cultivar & $\begin{array}{l}\text { Linolenic acid } \\
(\%)\end{array}$ & $\begin{array}{l}\text { Erucic acid } \\
(\%)\end{array}$ & $\begin{array}{l}\text { Glucosinolate } \\
\left(\mu \text { mole }^{-1}\right)\end{array}$ \\
\hline & \multirow{7}{*}{ Control } & Kodiak & $4.9^{\mathrm{ab}}$ & $0.17^{\text {bcd }}$ & $12.4^{\mathrm{b}}$ \\
\hline & & Traviata & $5.0^{\mathrm{a}}$ & $0.19^{a b c}$ & $13.5^{\mathrm{a}}$ \\
\hline & & Compass & $5.0^{\mathrm{a}}$ & $0.20^{\mathrm{ab}}$ & $13.8^{\mathrm{a}}$ \\
\hline \multirow{9}{*}{ Sep. 27} & & Diffusion & $4.9^{\mathrm{ab}}$ & $0.16^{\mathrm{cd}}$ & $12.2^{\mathrm{b}}$ \\
\hline & & Mehr2 & $5.1^{\mathrm{a}}$ & $0.21^{\mathrm{a}}$ & $14.4^{\mathrm{a}}$ \\
\hline & & Elvise & $4.8^{\mathrm{ab}}$ & $0.16^{\mathrm{cd}}$ & $12.0^{\mathrm{b}}$ \\
\hline & & Tassilo & $4.6^{\mathrm{b}}$ & $0.13^{\mathrm{e}}$ & $10.8^{\mathrm{c}}$ \\
\hline & Lsd (0.05) & & 0.36 & 0.02 & 0.95 \\
\hline & \multirow{4}{*}{ Restricted irrigation from pod formation } & Kodiak & $5.6^{\mathrm{a}}$ & $0.27^{\mathrm{ab}}$ & $17.9^{\mathrm{ab}}$ \\
\hline & & Traviata & $5.7^{\mathrm{a}}$ & $0.29^{\mathrm{a}}$ & $18.4^{\mathrm{a}}$ \\
\hline & & Compass & $5.3^{\mathrm{a}}$ & $0.24^{\mathrm{bc}}$ & $16.3^{\mathrm{c}}$ \\
\hline & & Diffusion & $5.3^{\mathrm{a}}$ & $0.23^{\mathrm{bc}}$ & $16.0^{\mathrm{c}}$ \\
\hline
\end{tabular}




\begin{tabular}{lllll}
\hline & Mehr2 & $5.6^{\mathrm{a}}$ & $0.26^{\mathrm{ab}}$ & $17.6^{\mathrm{b}}$ \\
& Elvise & $5.3^{\mathrm{a}}$ & $0.22^{\mathrm{bc}}$ & $15.6^{\mathrm{c}}$ \\
& Tassilo & $5.2^{\mathrm{a}}$ & $0.21^{\mathrm{c}}$ & $14.8^{\mathrm{d}}$ \\
\hline Lsd (0.05) & & $0.57^{\mathrm{a}}$ & 0.05 & 0.81 \\
\hline \multirow{4}{*}{ Kontrol } & Traviata & $6.6^{\mathrm{a}}$ & $0.40^{\mathrm{a}}$ & $22.4^{\mathrm{a}}$ \\
& Compass & $6.2^{\mathrm{a}}$ & $0.37^{\mathrm{ab}}$ & $20.9^{\mathrm{abc}}$ \\
& Diffusion & $6.1^{\mathrm{a}}$ & $0.34^{\mathrm{ab}}$ & $20.3^{\mathrm{abc}}$ \\
& Mehr2 & $6.4^{\mathrm{a}}$ & $0.34^{\mathrm{ab}}$ & $20.0^{\mathrm{bc}}$ \\
& Elvise & $6.0^{\mathrm{a}}$ & $0.39^{\mathrm{a}}$ & $21.9^{\mathrm{ab}}$ \\
& Tassilo & $5.9^{\mathrm{a}}$ & $0.32^{\mathrm{b}}$ & $19.7^{\mathrm{c}}$ \\
\hline Lsd (0.05) & & 0.71 & 0.06 & $2.00^{\mathrm{bc}}$ \\
\hline \multirow{4}{*}{ Restricted irrigation from pod formation } & Kodiak & $7.4^{\mathrm{a}}$ & $0.48^{\mathrm{ab}}$ & $25.5^{\mathrm{ab}}$ \\
& Traviata & $7.7^{\mathrm{a}}$ & $0.50^{\mathrm{a}}$ & $26.6^{\mathrm{a}}$ \\
& Compass & $7.4^{\mathrm{a}}$ & $0.46^{\mathrm{abc}}$ & $25.1^{\mathrm{ab}}$ \\
& Diffusion & $7.2^{\mathrm{a}}$ & $0.45^{\mathrm{abc}}$ & $24.4^{\mathrm{bc}}$ \\
& Mehr2 & $7.2^{\mathrm{a}}$ & $0.46^{\mathrm{abc}}$ & $24.9^{\mathrm{b}}$ \\
& Elvise & $7.1^{\mathrm{a}}$ & $0.44^{\mathrm{bc}}$ & $24.1^{\mathrm{bc}}$ \\
& Tassilo & $6.8^{\mathrm{a}}$ & $0.42^{\mathrm{c}}$ & $22.9^{\mathrm{c}}$ \\
\hline Lsd (0.05) & & 0.93 & 0.04 & 1.58 \\
\hline
\end{tabular}

Any two means sharing a common letter do not differ significantly from each other at $5 \%$ probability

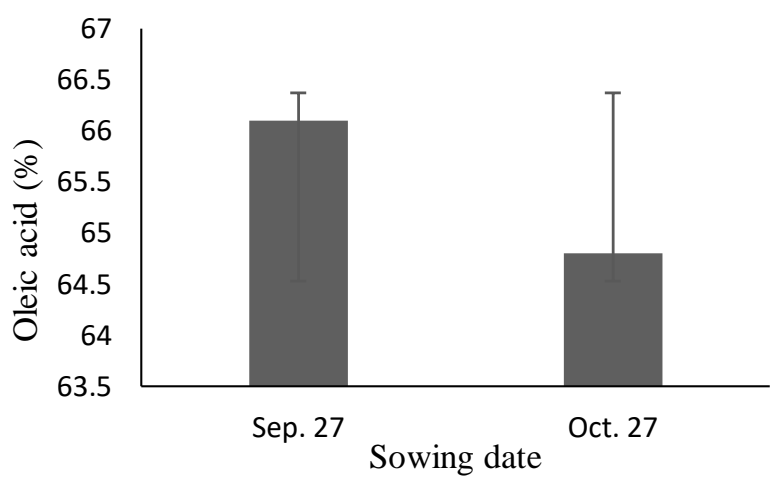

Figure 5. Mean comparison of simple effect of sowing date on oleic acid (The vertical bars indicated LSD).

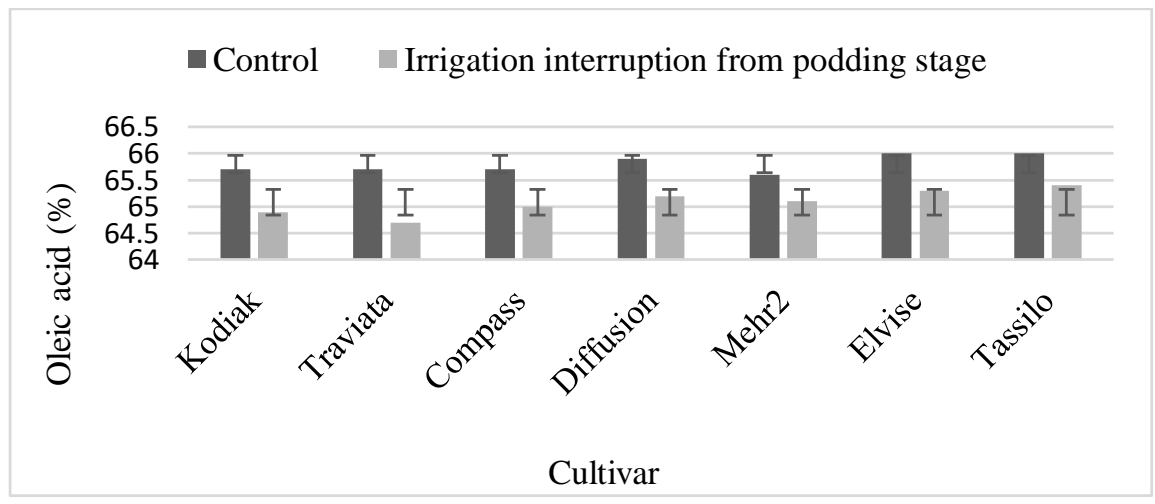

Figure 6. Mean comparison of interaction effect of irrigation $\times$ cultivar on oleic acid (The vertical bars indicated LSD). 


\section{Erucic Acid}

The studied cultivars had a significant difference for erucic acid in irrigation treatments on the two timely and delayed sowing dates (Table 2); so that in the timely sowing date (September 27), the lowest amount of erucic acid in normal irrigation and irrigation interruption from podding stage was observed in the Tassilo hybrid with means of 0.13 and $0.21 \%$, respectively. In addition, in the delayed sowing date (October 27) in normal irrigation treatment, Tassilo and Elvise hybrids with the mean of $0.32 \%$, and in the treatment of irrigation interruption from the podding stage, the Tassilo hybrid with the mean of $0.42 \%$ had the least amount of erucic acid.

The comparison results of the means of tested cultivars on timely sowing date (September 27) showed that the Compass hybrid had the lowest percentage of increase (20\%) in conditions of irrigation interruption from the podding stage compared to the normal irrigation, while on the delayed sowing date (October 27), the promising line of Mehr2 (Mahtab cultivar) exhibited the lowest percentage of increase (17.9\%) in the conditions of irrigation interruption from podding stage compared to the normal irrigation. In this regard, Ullah et al. (2012) reported that drought stress increased the percentage of erucic acid of canola as well as reducing its percentage of oleic acid and linoleic acid (Ullah, Bano, \& Nosheen, 2012). Accordingly, considering that the amount of erucic acid is a key indicator for canola and its edible consumption (Gecgel, Demirci, Esendal, \& Tasan, 2007), in both of timely and delayed sowing dates and in all irrigation conditions, the amount of erucic acid has been in the standard level.

\section{Seed Glucosinolate}

Significant difference between the amounts of glucosinolate in the tested cultivars on timely sowing date (September 27) revealed that Compass hybrid had the lowest percentage of increase (18.1\%) in irrigation interruption from podding stage compared to the normal irrigation. While in the delayed sowing date (October 27), the promising line of Mehr2 (Mahtab cultivar) showed the lowest percentage of increase $(13.6 \%)$ in irrigation interruptions from the podding stage compared to the normal irrigation (Table 2). Comparison of the means revealed that on the timely sowing date (September 27), the lowest amount of seed glucosinolate in conditions of normal irrigation and irrigation interruption from the podding stage was observed in the Tassilo hybrid with the means of 10.8 and $14.8 \mu$ mole $\mathrm{g}^{-1}$ of meal, respectively. While on the delayed sowing date (October 27), in the normal irrigation treatment, Elvise hybrids with a mean of $19.7 \mu$ mole $\mathrm{g}^{-1}$ of meal and in the treatment of irrigation interruption from podding stage, The Tassilo hybrid, with the mean of $22.9 \mu$ mole $\mathrm{g}^{-1}$, had the lowest amount of seed glucosinolate.

Based on this study's results, in both timely and delayed sowing dates and in all irrigation conditions, the glucosinolate level was standard and less than $30 \mu \mathrm{mole}^{-1}$ of meal. In addition, in the delayed sowing date and the late season drought stress, the promising line of Mehr2 (Mahtab cultivar) had less increase in the amounts of erucic acid and seed glucosinolate compared to the normal irrigation conditions. Other researchers like Grant et al. (2003) and Jan et al. (2002) also reported that glucosinolate level and fatty acid composition in different canola cultivars depended on environmental conditions (Grant, Clayton, \& Johnston, 2003; Jan, Khan, Khan, Khan, \& Khattak, 2002). Sulisbury et al. (1987) reported that increased glucosinolate reduced the quality and nutritional value of canola meal (Salisbury, Sang, \& Cawood).

\section{CONCLUSION}

The impossibility of timely cultivation of canola and late season draught stress is one of the significant factors threatening the development of the cultivated area and the successful production of canola, especially in cold temperate regions with dry and semi-arid climates. In delayed sowing date and late season drought stress conditions (irrigation interruption from podding stage), Tassilo hybrid with the highest seed yield (2935 $\left.\mathrm{kg} \mathrm{ha}^{-1}\right)$ and low erucic acid and glucosinolate level is recommended for delayed cultivation of temperate cold regions with dry and semi-arid climates due to its acceptable quantity and quality of seed oil for canola cultivation development. 


\section{CONFLICT OF INTEREST}

All authors declare do not have any conflicts of interest.

\section{REFERENCIAS}

Aslam, M. N., Nelson, M. N., Kailis, S. G., Bayliss, K. L., Speijers, J., \& Cowling, W. A. (2009). Canola oil increases in polyunsaturated fatty acids and decreases in oleic acid in drought-stressed Mediterranean-type environments. Plant Breeding, 128(4), 348-355.

Damirchi, S. A., Savage, G. P., \& Dutta, P. C. (2005). Sterol fractions in hazelnut and virgin olive oils and 4, 4'dimethylsterols as possible markers for detection of adulteration of virgin olive oil. Journal of the American Oil Chemists' Society, 82(10), 717-725.

Daneshian, A. M., Ahmadzadeh, A. R., Shahriar, H. A., \& Khanizadeh, A. R. (2008). Effect of sowing dates on grain and biological yield, oil and meal protein percentage in three cultivars of rape (Brassica napus L.). Res. J. Biol. Sci, 3, 729-732.

Enjalbert, J.-N., Zheng, S., Johnson, J. J., Mullen, J. L., Byrne, P. F., \& McKay, J. K. (2013). Brassicaceae germplasm diversity for agronomic and seed quality traits under drought stress. Industrial Crops and Products, 47, 176-185.

Farooq, M., Wahid, A., Kobayashi, N., Fujita, D., \& Basra, S. M. A. (2009). Plant drought stress: effects, mechanisms and management. In Sustainable agriculture (pp. 153-188): Springer.

Flagella, Z., Rotunno, T., Tarantino, E., Di Caterina, R., \& De Caro, A. (2002). Changes in seed yield and oil fatty acid composition of high oleic sunflower (Helianthus annuus L.) hybrids in relation to the sowing date and the water regime. European journal of agronomy, 17(3), 221-230.

Gecgel, U., Demirci, M., Esendal, E., \& Tasan, M. (2007). Fatty acid composition of the oil from developing seeds of different varieties of safflower (Carthamus tinctorius L.). Journal of the American Oil Chemists' Society, 84(1), 47-54.

Grant, C. A., Clayton, G. W., \& Johnston, A. M. (2003). Sulphur fertilizer and tillage effects on canola seed quality in the Black soil zone of western Canada. Canadian Journal of Plant Science, 83(4), 745-758.

Hanson, B., Schwankl, L. J., \& Fulton, A. (1999). Scheduling irrigations: When and how much water to apply (Vol. 3396): University of California Irrigation Program.

ISO. (1992). Oilseeds-Determination of oil Content-Method using continuous-wave low-resolution nuclear magnetic resonance spectrometry

Jan, A., Khan, N., Khan, N., Khan, I. A., \& Khattak, B. (2002). Chemical composition of canola as affected by nitrogen and sulphur. Asian Journal of Plant Sciences.

Javidfar, F., Ripley, V., Zeynali, H., Abd Mishani, S., Shahnezhat, B. A., Tavakol, A. R., . . . Jafarieh, E. (2007). Heritability of fatty acids composition in spring oilseed rape (brassica napus 1.).

Kadkhodaie, A., Razmjoo, J., Zahedi, M., \& Pessarakli, M. (2014). Oil content and composition of sesame (Sesamum indicum L.) genotypes as affected by irrigation regimes. Journal of the American Oil Chemists' Society, 91(10), 1737-1744.

Koutroubas, S. D., \& Papakosta, D. K. (2005, 2005). Adaptation, grain yield and oil content of safflower in Greece.

Majidi, M. M. (2015). Effect of drought stress on yield and some physiological traits in Canola varieties. Journal of Plant Process and Function, 3(9), 59-70.

Makkar, H. P. S., Siddhuraju, P., \& Becker, K. (2007). A laboratory manual on quantification of plant secondary metabolites.,(Human Press: Totowa, NJ).

Nasr, N., Khayami, M., Heydari, R., \& Jameei, R. (2006). Genetic diversity among selected varieties of Brassica napus (Cruciferae) based on the biochemical composition of seeds.

Pritchard, F. M., Eagles, H. A., Norton, R. M., Salisbury, P. A., \& Nicolas, M. (2000). Environmental effects on seed composition of Victorian canola. Australian Journal of Experimental Agriculture, 40(5), 679-685.

Qian, W., Li, Q., Noack, J., Sass, O., Meng, J., Frauen, M., \& Jung, C. (2009). Heterotic patterns in rapeseed (Brassica napus L.): II. Crosses between European winter and Chinese semi-winter lines. Plant Breeding, 128(5), 466-470.

Salisbury, P., Sang, J., \& Cawood, R. (1988). Genetic and environmental factors influencing glucosinolate content in rapeseed in southern Australia.

Seyed Sharifi, R. (2017). Industrial plants. University of Mohaghegh Ardabili Press, 432.

Starner, D. E., Hamama, A. A., \& Bhardwaj, H. L. (2002). Prospects of canola as an alternative winter crop in Virginia. Trends in new crops and new uses. ASHS Press, Alexandria, VA, 127-130.

Ullah, F., Bano, A., \& Nosheen, A. (2012). Effects of plant growth regulators on growth and oil quality of canola (Brassica napus L.) under drought stress. Pak. J. Bot, 44(6), 1873-1880. 